\title{
HOSPITALITY INDUSTRY DURING COVID-19 CRISIS: REVIEW OF THE CURRENT SITUATION AND SUSTAINABLE POST-CRISIS RESPONSE
}

\author{
Oḷegs N̦ikadimovs \\ "HOTEL SCHOOL” Hotel Management College, Latvia \\ Aḷina Rodčenkova \\ “HOTEL SCHOOL” Hotel Management College, Latvia
}

\begin{abstract}
This study, titled "Hospitality Industry During COVID-19 Crisis: Review of the Current Situation and Sustainable Post-Crisis Response", is a review of published studies, assessing the current research efforts in the hospitality industry that was heavily impacted by the COVID-19 global pandemic, as well as possible sustainable crisis management solutions. In response to the crisis, caused by virus outbreak and followed by the travel bans, many hotels were forced to close their doors temporarily or even forever. Such a deep crisis in the hospitality industry resulted in many problems, especially social problems among the employees of the industry. The study has utilised secondary research methodology to conduct a literature review; qualitative content analysis has been applied to the selected academic pieces of literature, journal articles, published researches and thesis papers, government reports, case studies, UNWTO monthly reports. The results revealed approaches and the most popular research directions, as well as possible crisis management solutions and strategies. The findings are highlighting the challenges in tourisms and hospitality industry in the wake of ongoing pandemic; the study lists possible post-crisis sustainable strategic solutions, as well as directions for the future research efforts.
\end{abstract}

Keywords: COVID-19, crisis, hospitality industry, management, sustainability.

\section{Introduction}

The year 2020 became the "new normal" for all people around the globe, the reason for it is known as COVID-19 pandemic. On December 8, 2019, the government of Wuhan, China, has declared that health authorities were discovering and reporting on dozens of novel virus cases, identified as coronavirus (Bakar \& Rosbi, 2020). Since that time, COVID-19, a new strain of SARS - SARS-CoV, has developed into a global pandemic and has spread across many countries.

The global hospitality industry has never been affected by a virus outbreak of such a size in past 30 years (Nkengasong, 2020). Despite of positive changes in the environmental field, other aspects such as economic and social problems 
now are a major issue for hospitality industry establishments and employees (United Nations, 2020). As public health concerns started to escalate in March 2020 and many borders were closed, travel bans and other national and international restrictions implemented. As a result, hotels have lost revenues, in October 2020 the number of nights spent by at various accommodation establishments was 49 thousand, which is a decrease of $82.8 \%$ (Central Statistical Bureau of Latvia, 2020). Due to this, compared with the year 2019 number of unemployed started to growth rapidly (State Employment Agency Republic of Latvia, 2020). Despite the recovery between May and August, the tourism related turnover in September was only at a level of around $72 \%$ of February. The strongest declines between September and February were recorded in Portugal (89.1\%), in Sweden (-80.9\%), in Spain (-77.2\%), and in Latvia (-77.0\%) (Eurostat, 2020). According to projections from March 2020, the travel and tourism sector in Germany is expected to be the most affected in Europe by the coronavirus (COVID-19) outbreak, with an estimated 1.6 million jobs at risk (Statista, 2020). Statistics of World Travel \& Tourism Council show that tourism industry generates 10.3\% of global GDP, that is equal to 7.35 trillion EUR. Back in 2019 tourism industry created 330 million jobs, 1 in 10 jobs around the world. The latest survey illustrates that 142.6 million of people lost their job, and GDP decreased for 3 billion EUR in 2020 (WTTC, 2020).

\section{Methodology}

This study reviews published literature in order to assess the current research efforts investigating the tourism and hospitality industry in the wake of the COVID-19 global pandemic. The study aims to measure the negative impact and to collect the ideas to address the negative consequences of COVID-19 in the hospitality industry by conducting qualitative content analysis. This study has utilised secondary research method to conduct literature review - academic pieces of literature, journal articles, published researches or thesis papers, government reports, case studies, UNWTO monthly reports. Data collection method was utilised to find and review relevant published papers from the year 2020, keywords were defined in order to facilitate systematic review - COVID-19, hospitality industry, response, sustainability. Google Scholar was used as database search source. A number of keywords were used to search for the relevant literature and more than 120 articles that contain the keywords were found, however, after screening and filtering the relevant results and estimating the available resources, exclusions were made to the following sources that are not open access, not in English language, not peer-reviewed, newspaper articles, commentaries, web-page entries, blogs viewpoints, presentations. 10 articles were selected for the inclusion (see Table 1), as the open access resources are rather 
scarce and the COVID-19 pandemic is still ongoing and is rather novel, many of the researches are still on the way.

\section{Literature Review}

Hospitality industry blossoms on the international and national visitations and considerable effort and resources are being placed into attraction of the visitors, but due to the ongoing global pandemic, travel restrictions and other limitations are being imposed across the hospitality and tourism industry. These travel bans, border closures, additional limitations, room reservation and event cancellations, quarantine and self-isolation requirements and fear of virus spread and infection, have placed extreme difficulties and challenges on tourism and hospitality sectors (Gössling et al., 2020).

Table 1 Characteristics of the Relevant Studies (created by the authors)

\begin{tabular}{|c|c|c|c|}
\hline Title and Authors & $\begin{array}{l}\text { Segment of } \\
\text { Industry }\end{array}$ & $\begin{array}{l}\text { Geographic } \\
\text { Location }\end{array}$ & Approach \\
\hline $\begin{array}{l}\text { "Social Sustainability in COVID-19 Crisis: } \\
\text { The Case of the Hotel Industry"; Beka } \\
\text { Katsadze; Daniel Milojevic (2020). }\end{array}$ & $\begin{array}{l}\text { Accommodation } \\
\text { Sector }\end{array}$ & Global & $\begin{array}{l}\text { Exploratory } \\
\text { study, } \\
\text { thesis }\end{array}$ \\
\hline $\begin{array}{l}\text { "Hospitality and tourism industry amid } \\
\text { COVID-19 pandemic: Perspectives on } \\
\text { challenges and learnings from India"; } \\
\text { Vikrant Kaushal, Sidharth Srivastava } \\
\text { (2020). }\end{array}$ & $\begin{array}{l}\text { Tourism and } \\
\text { hospitality } \\
\text { industry }\end{array}$ & India & Review \\
\hline $\begin{array}{l}\text { "The Hospitality Industry in the Face of the } \\
\text { COVID-19 Pandemic: Current Topics and } \\
\text { Research Methods"; Mohammad Reza } \\
\text { Davahli, Waldemar Karwowski, Sevil } \\
\text { Sonmez, Yorghos Apostolopoulos (2020). }\end{array}$ & $\begin{array}{l}\text { Hospitality } \\
\text { Industry }\end{array}$ & Global & Review \\
\hline $\begin{array}{l}\text { "COVID-19: The effects of job insecurity } \\
\text { on the job engagement and turnover intent } \\
\text { of deluxe hotel employees and the } \\
\text { moderating role of generational } \\
\text { characteristics"; Hyo Sun Jung, Yoon Sik } \\
\text { Jung, Hye Hyun Yoon (2020). }\end{array}$ & $\begin{array}{l}\text { Accommodation } \\
\text { Sector }\end{array}$ & South Korea & $\begin{array}{l}\text { Exploratory } \\
\text { study, } \\
\text { survey }\end{array}$ \\
\hline $\begin{array}{l}\text { "The COVID-19 Crisis and Sustainability in } \\
\text { the Hospitality Industry", Jones, Peter; } \\
\text { Comfort, Daphne (2020). }\end{array}$ & $\begin{array}{l}\text { Hospitality } \\
\text { Industry }\end{array}$ & Global & Review \\
\hline $\begin{array}{l}\text { "Strategic Management in the Hotel } \\
\text { Industry: Proposed Strategic Practices to } \\
\text { Recover from COVID-19 Global Crisis"; } \\
\text { Dimitrios, B., Christos, P., Ioannis, R., \& } \\
\text { Vasiliadis, L. (2020). }\end{array}$ & $\begin{array}{l}\text { Accommodation } \\
\text { sector }\end{array}$ & Global & Review \\
\hline
\end{tabular}


Nikadimovs \& Rodčenkova, 2021. Hospitality Industry During Covid-19 Crisis: Review of the Current Situation and Sustainable Post-Crisis Response

\begin{tabular}{|c|c|c|c|}
\hline $\begin{array}{l}\text { "Strategic responses of the hotel sector to } \\
\text { COVID-19: Toward a refined pandemic } \\
\text { crisis management framework"; Dung Lea, } \\
\text { Giang Phi (2020). }\end{array}$ & $\begin{array}{l}\text { Accommodation } \\
\text { sector }\end{array}$ & Global & Review \\
\hline $\begin{array}{l}\text { "Crisis Management Practices in Tourism } \\
\text { SMEs During the COVID-19 Pandemic"; } \\
\text { Marko Kukanja, Tanja Planinc, and } \\
\text { Marijana Sikošek (2020). }\end{array}$ & $\begin{array}{l}\text { Tourism and } \\
\text { Hospitality } \\
\text { Industry }\end{array}$ & Slovenia & $\begin{array}{l}\text { Exploratory } \\
\text { study, } \\
\text { survey }\end{array}$ \\
\hline $\begin{array}{l}\text { "COVID-19 and China's Hotel Industry: } \\
\text { Impacts, a Disaster Management } \\
\text { Framework, and Post-Pandemic Agenda"; } \\
\text { Fei Haoa, Qu Xiaob, Kaye Chonc (2020). }\end{array}$ & $\begin{array}{l}\text { Accommodation } \\
\text { sector }\end{array}$ & China & Review \\
\hline
\end{tabular}

Many recent studies have been focused on COVID-19 crisis in the hospitality industry and only some of them reviewed the problems of sustainability and possible post-crisis responses. The purpose of this review is to assess previously conducted researches specific to the crisis, sustainability and how they have reviewed strategic solutions for the hospitality industry. Researchers conducted their studies to assess relationship between tourism and hospitality industry and sustainable crisis responses and have proposed various crisis response frameworks and strategies (Jones \& Comfort, 2020).

COVID-19 pandemic outbreak has forced many businesses to close, leading to an unprecedented disruption of commerce in most industry sectors. Retailers and brands face many short-term challenges, such as those related to health and safety, the supply chain, the workforce, cash flow, consumer demand, sales, and marketing (Dounthu \& Gustaffson, 2020). New virus has been described by Kristalina Georgieva, Managing Director of the International Monetary Fund, as "a crisis like no other" (World Economic Forum, 2020). COVID-19 crisis has not only provided a range of major challenges for the hospitality industry, but it has also showcased some environmental causes that needs to be addressed and may be crucial for the transitional process to a more sustainable future. The crisis has also showcased some of the inherent contradictions and complexities within the concept of sustainable development in the hospitality industry, and has suggested some radical solutions to the sustainability challenges and responses (Katsadze \& Milojevic, 2020).

According to the World Commission on Environment and Development (WCED), "sustainability" is a term, which is usually used as "sustainable development" (Choy, Chong, \& Verma, 2015). Sustainable development aims to achieve the optimal resources usage in such a away, that it serves and benefits the society, as well as guarantees the rights of the future generations and addresses all the areas within the mentioned societies, might it be water, food, health, services, income, education, awareness, good governance, etc. and is a crucial requirement 
to cope the negative effects of COVID-19 pandemic and the following crisis (Al Eid \& Arnout, 2020). The concept of sustainable development is frequently described by the triple bottom line model (see Figure 1) and recognizes three measurements: social, economic and environmental. In this case, sustainability is achieved when all aspects are fulfilled at one time (GRI, 2006).

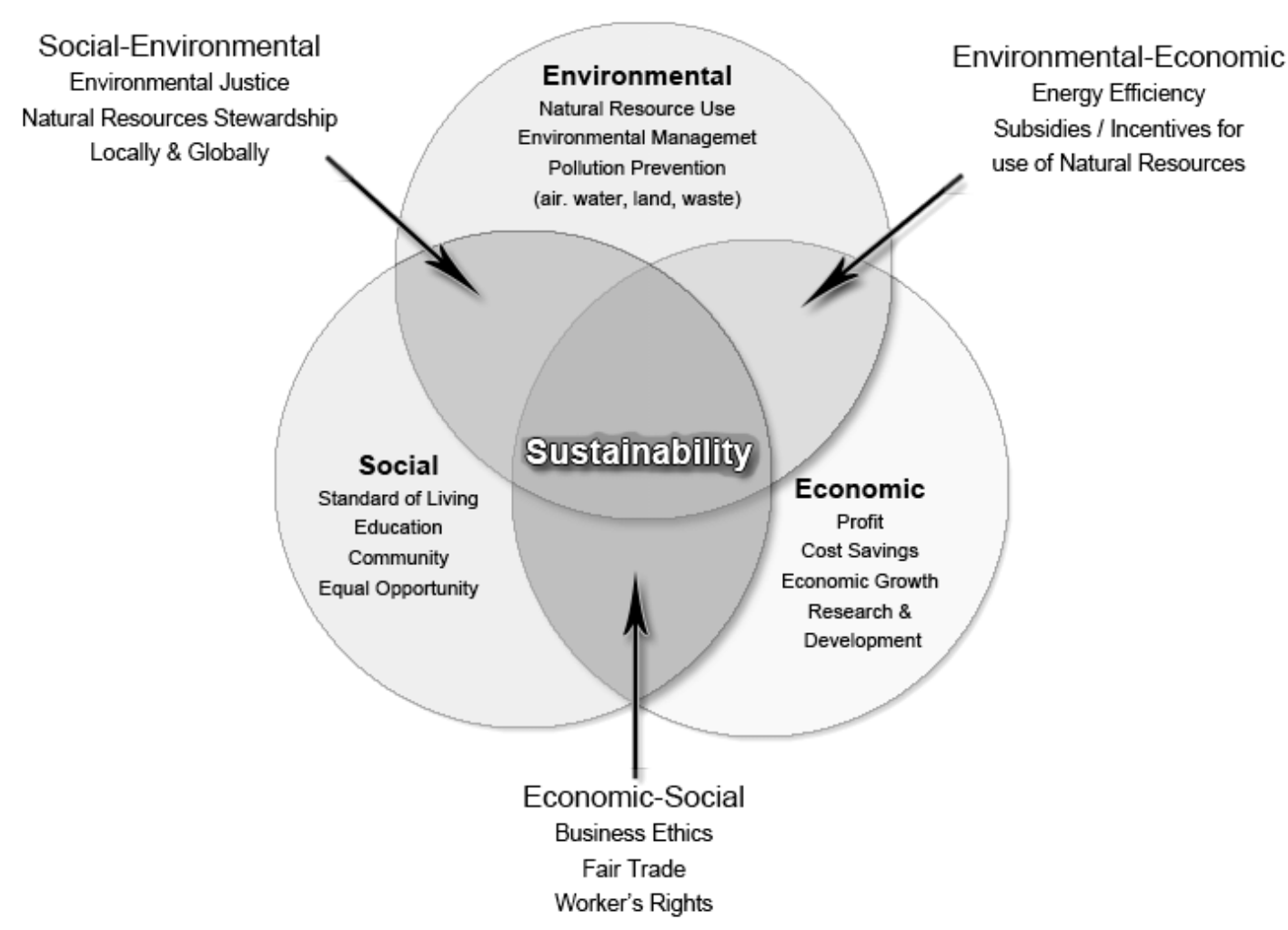

Figure 1 Triple Bottom Line (Source: Sustainability Assessment and Reporting for the University of Michigan's, 2002, p.8)

COVID-19 crisis has showcased an array of required environmental improvements, including marked reductions in pollution levels and greenhouse gas emissions, following the closure of many power generation plants and factories, rapid decrease in the number of domestic and international arrivals and the travel restrictions on the movement of people in cars and similar vehicles (Jones \& Comfort, 2020). According to scholars, COVID-19 made a positive impact on environments, however, two others aspects are affected negatively. Social factor became the most important part of sustainability, as now, during pandemic, such social aspects as health and safety are number one priority. Due to virus spread became a huge crisis, previously conducted surveys describe the significance of crisis management within organizations (Dounthu \& Gustaffson, 2020). Virus spread was unknown crisis type, and how analyses show- there were 
N̦ikadimovs \& Rodčenkova, 2021. Hospitality Industry During Covid-19 Crisis: Review of the Current Situation and Sustainable Post-Crisis Response

not good predictions and qualitative plans for resolving problems. When the crisis hit, companies were mainly focused on business and money, and only, when significance of stakeholders started to grow- organizations understood, why culture of company and its people are important. Corporate social sustainability has been viewed of an increased importance within the corporate field, and many of the leading companies in the hospitality industry have developed sustainability programmes aimed to address governance issues and to design them into their business strategies, as well as environmental, social and economic factors. All of society is affected and it has led to dramatic changes in how businesses act and consumers behave (Katsadze \& Milojevic, 2020).

Hospitality industry was one of significant markets in the World, until society was forced to face a COVID-19 pandemic spread. The historical growth of tourism sharply declined and accommodation sector became the most affected, since that "sustainability" became an initial basis of hospitality industry in terms of economy and society. Companies, that integrated sustainability practices and methods of transparency to their stakeholders into their business operations prior to the COVID-19 outbreak have put even stronger focus on it now, during the crisis (Dounthu \& Gustaffson, 2020).

Nowadays, social sustainability gains more popularity, because instead of preserving only natural wealth and economic stability, social aspect encourages society happiness, equality and well-being (Caradonna, 2014). According to Western Australia Council of Social Services (WACOSS), "Social sustainability occurs when the formal and informal processes; systems; structures; and relationships actively support the capacity of current and future generations to create healthy and livable communities. Socially sustainable communities are equitable, diverse, connected and democratic and provide a good quality of life" (WACOSS, 2003).

James et al. (2015) emphasize and also measure the successful social sustainability development of the organization using 12 factors: 1) Social equity; 2) Livability; 3) Community development; 4) Social capital; 5) Human rights; 6) Labour rights; 7)Place making; 8) Social responsibility; 9) Social justice cultural; 10) Cultural competence; 11) Community resilience and 12) Human adaption. All previously mentioned factors consider, that all activities taken by social sustainability development are claimed for human well-being, in terms of company, for stakeholders. The main theory applicable here is "Creating Shared Value" (CSV) model, which suggests social responsibility as a core value of the company. In the offered model Kramer \& Porter (2011) illustrate three main approaches for companies to create CSV: 1) Perception of needs, products, and customers. Approach is responsible for meeting societal needs through products, and serving unserved or underserved customers; 2) Redefining productivity in the value chain by utilizing resources, energy, suppliers, logistics, 
and employees differently; 3) Improvement of local and regional business environment. Improving skills, the supplier base, the regulatory environment, and the supporting institutions that affect the business (Kramer \& Porter, 2011).

The impacts of the current COVID-19 pandemic will be more pronounced and longer lasting in the hospitality industry impacting all pillars of suitability, especially in the wake of absence of immediate vaccine to create immunity in the majority of the population. This is critical for the tourism and hospitality sector because of the perpetuity exhibited by the outbreak (Kaushal \& Srivastava, 2020). The effects are going to remain for a longer duration and sectors that thrive on social contacts such as tourism and hospitality need to embrace for tumultuous times ahead. Kaushal and Srivastava (2020) are noting that negative effects of pandemic on tourism and hospitality in India are growing within the whole sector and are resulting in unemployment rates. The potential job loss in tourism and hospitality has been estimated at 38 million, which is $70 \%$ of the tourism industry employees (Radhakrishna, 2020). The same authors, Kaushal and Srivastava (2020), have evaluated some critical reflections from the industry experts on latent redundancy of employees in the accommodation sector, where the experts are have voice an opinion that post COVID-19, hospitality organisations will surely consolidate their business models based on the loss handled and market conditions for the future; workforce reduction is a high possibility.

Davahli et al. (2020) in their systematic review of the published literature on COVID-19 consequences for the hospitality industry; the included articles focused on the impact of the pandemic on the hospitality industry, including hospitality employee's issues, loss of job positions, revenue negative growth, the spread of COVID-19 in the hospitality industry, dramatically falling market demand, perspectives of the recovery for the industry, safety and health issues, traveller's behaviour and patterns, as well as changing preferences and habits of customers. Altogether, 50 papers were reviewed in this study, where the authors have reviewed the characterization and description of the hospitality industry in COVID-19 crisis time and identified the methodologies that were utilised to reserach the impact of global pandemic on the hospitality industry. The reviewed papers were systemized and assessed thoroughly, and the authors have identified the main research directions and topics as follows (from the most popular to the least) - recovery of the hospitality industry; market demand; revenue loss; the health and safety / COVID-19 spreading in the industry; loss of the jobs; job insecurity issues; changing customer travelling behaviours; social costs and impacts of COVID-19 pandemic (Davahli et al., 2020).

Employment issues in the hospitality industry during the COVID-19 pandemic crisis on the U.S. labour market were assessed and the study conclused that about 13 million employees lost their job positions from March 14 to 28, 2020 (Cajner et al., 2020). The same study revealed that the service and tourism 
industries were amongst those the most heavily impacted, and the negative impact is much greater that the one experienced during the years of the Great Recession of the 1930s, when about 9 million employment positions were lost (in comparison to 13 million due to COVID-19 pandemic).

Qiu et al. (2020) in their study have assessed the social costs, customer preferences and changing travel behaviours, survey-based method was utilised and the researchers concluded that the most of the country residents are willing to suffer negative economic impacts if the health risks are reduced, but this willingness differs based on respondents' age and income levels. The study investigated how residents of three Chinese urban destinations would react to travel and other restrictions, as well as social costs during COVID-19 pandemic.

Another study focused on conducting a survey amongst 45 small hospitality businesses, to assess the resilience and to address main concerns in regards of the COVID-19 pandemic. The authors attempted to study the processes how hospitality small business enterprises are handling the limitation and disruptions in their day-to-day operations. Content analysis have been performed and the results showcased theoretical owners-managers' actions and alternatives, when confronted with the COVID-19 pandemic, nine theoretical dimensions were highlighted (Duarte Alonso et al., 2020). Another survey assessed COVID-19 pandemic impact on the traveller behaviour changing patterns and the authors has concluded that it had significantly amended the customer decision making process, whether to travel next year or in foreseeable future. The authors reported that respondents have displayed high levels of concern about accommodation facilities health and safety, hygiene of recreational sites and public vehicles; altogether health and safety concerns are playing a significant role in the customer decision making process during COVID-19 pandemic times (Nazneen et al., 2020). Market demand decrease (18\%), revenue loss (16\%) and an overall recovery of the industry (19\%) were among the top research topics of the reviewed papers in this study (Davahli et al., 2020).

Job insecurity was assessed in another paper, namely the perception of deluxe hotel employees in South Korea. The authors have sent 400 copies of questionnaires to 8 five-star hotels out of 22 located in Seoul, in an attempt to assess the significance of COVID-19 impact on employees' engagement and hotels' revenue losses. The findings have highlighted that job insecurity caused by COVID-19 pandemic has negative impact on employees and their engagement, that can result in negatively affecting already catastrophically low revenues (Jung et al., 2020). Karatepe et al. (2020) have concluded that job insecurity has a direct negative impact on the engagement and motivation levels of employees and greatly hinders social sustainability aspects and well-being of employees, both physical and psychological aspects. Previously numerous studies that addressed job insecurity aspects were conducted, but only very few addressed this issue in 
the wake of global COVID-19 pandemic. The authors were amongst the first ones to conduct empirical study to assess the significance of job insecurity negative effects on employees' engagement during COVID-19 pandemic (Jung et al., 2020).

\section{Recovery management plans}

Jones and Comfort (2020) carried out a study that reflected on some of the changes in the correlation between sustainability and the hospitality industry during COVID-19 pandemic. In the paper the authors reviewed the origins of the crisis, assessed the role of the hospitality industry in economic and social aspects. It was suggested that changes in the environment of the hospitality enterprise and their connection to the COVID-19 virus spread have been overlooked by the researchers' community and should be studied more extensively. It was recommended that sustainable development plans should further on include the research of the emergence of infectious diseases and action planning (Di Marco et al., 2020).

Corporate social responsibility has become an important business aspect for many hospitality companies, many hospitality companies have developed their corporate sustainability programmes (Jones et al., 2014). The main focus of the hospitality industry enterprises is to adapt their international corporate sustainability policies to local legislation and values, and COVID-19 has provided some opportunities, as well as some challenges for that (Ertuna et al., 2019). COVID-19 pandemic will have serious consequences for the hospitality industry, traditional business models, financial markets and capital availability. Marketing campaigns designed to promote hospitality enterprises and to attract revenues, might be favoured over environmental and social sustainability issues that have been an integral part of corporate sustainability programmes. COVID-19 crisis shows the need to be better prepared for the challenges that might arise with future pandemic or similar crises and to better assess the failure to arrange such preparations (Jones \& Comfort, 2020). Bell et al. (2018) reviewed strategic management processes in the hospitality industry and attempted to assess crisis recovery management strategies that might help hotels to respond effectively to the ongoing crisis. The authors have presented strategic management actions: 1) promotion of a safety umbrella; 2) use of technology and innovation; 3) satisfaction of the stakeholder's needs and empowerment of guests' relationships 4) financial pillow.

In some particular cases, the expense per one reservation may grow up to $50 \%$ due to additional COVID-19 health and safety measures, including additional shifts, specific cleaning materials, operating less than $50 \%$ of the capacity, and leaving hotel rooms unoccupied for several days between the customers (Sigala, 2020). The hospitality enterprises should count on financial expenses and be ready to respond to any suspicious case of illness, moreover, the 
hospitality enterprises should develop internal policies and protocols on how to handle suspicious cases and eliminate potential risk to the employees, hence improving social sustainability aspects and well-being of the employees (Armstrong et al., 2020). Moreover, to protect employees, all hospitality enterprises should embrace contactless technology for the majority of internal processes, smart kiosks can be installed around the premises to eliminate touchpoints and possible contaminated surfaces (Dehler, 2020). Safety of employees and other stakeholders should be the main strategic priority, additional attention to the cutting edge technology should be paid, guest relationships strengthened, needs satisfied; thus the hospitality industry enterprises will be able to create a "financial pillow" to recover from the crisis effects and withstand the possible second or third wave of COVID- 19 pandemic (Bell et al., 2018).

Dung and Giang (2020) in their study have reviewed 219 articles and publications collected through various media outlets and have attempted to map out "strategic responses" for the accommodation sector as well as highlighted the challenges to address during COVID-19 global pandemic. Strategic framework of hotel pandemic crisis management was suggested, that consists of five phases Phase 1: Pre-event and early symptom; Phase 2: Emergency; Phase 3: Crisis; Phase 4: Recovery; Phase 5: Resolutions.

Domestic traveling will quickly bounce back and will be the main focus for accommodation sector to recover, when the spread of the virus will slow down, the number of positive cases will drop and the authorities will loosen travel restrictions (Oliver, 2020). Recovery process and strategies are targeting domestic travellers mainly, as international travel restrictions will be in effect for longer period of time. The hotels should adapt digital technologies, as digitalization reduces the physical contact and infection risk (Maaty, 2020). It was suggested that after the crisis the whole system may not return to a previous condition, as parts of the system are likely to have changed irrevocably. The challenges may arise, such as finding ways to maintain the "human touch" of the service and finding new balance with automation (Rivera, 2020); deployment of companion robots to mitigate guests' frustration and feeling of loneliness and isolations for quarantine time (Henkel et al., 2020). Health-oriented tourism and wellness and spa hotel might be of the customer preferences after the end of the pandemic due to their slow tourism nature and comforting ambience (Wen et al., 2020). The aftermath of the COVID-19 pandemic maybe severe enough and a proportion of hospitality industry's SMEs will not restart their operations, as they will not have sufficient resources to do so, thus providing opportunities for larger individual and chain hotels to take over (Crouch et al., 2020).

Hao at al. (2020) in their exploratory study have reviewed the overall negative impact of COVID-19 pandemic on China's hospitality industry and accommodation services. The authors have also proposed management 
framework to address the pandemic consequences with principles, methods, stages and strategies. China was the very first country to be hit with COVID-19 and it negatively impacted the hospitality industry. The situation can be salvaged with a crisis management plan and effective disaster management strategies that hospitality industry enterprises can utilise to minimize risks and to facilitate the recovery process (Ritchie \& Jiang, 2019). Depending on the crisis type, appropriate methods should be used, as the disaster management strategies are related to the nature of the disaster (Hall, 2010). The proposed solutions and phases mostly addressing the finical consequences of the pandemic, the strategies to recover business revenues, adapt new customer-centric service techniques and technology, as well as attract investments for the industry revival. Sustainability aspect is majorly overlooked in this study.

Kukanja et al. (2020) in their study reviewed 574 online questionnaires, that were filled in by small and medium enterprises' (SME) managers and in order to attempt to design a framework for crisis management in the related enterprises affected by COVID-19 pandemic. The authors concluded that the main focus of the SME's should be cost control, employees, employee's perception of the organization values, as well as sustainable customer-centred marketing practices.

Crisis is defined as: "a significant threat to operations that can have negative consequences if not handled properly" (Coombs, 2007). The consequences caused by crisis were defined by Bundy et al. as devastating and are determined as follows: "an event perceived by managers and stakeholders as highly salient, unexpected, and potentially disruptive can threaten an organization's goals and have profound implications for its relationships with stakeholders." As a result, the outcome can be loss of brand value and reputation, problems within financial strength and employee's perception about the company (Bundy et al., 2017). In this case, effective crisis management handles all the threats sequentially. The primary concern in a crisis has to be public safety, only than reputation and financial concerns are considered to be improved (Coombs, 2007).

Sustainable crisis management plays a crucial role in restoring hospitality industry establishments in crisis, including improvement of guests' confidence, reducing crisis' impact on tourism and enhancing security (Beirman, 2003). In the tourism industry crises raise from various reasons, in terms of internal sources, crisis may be caused by internal problems within organization, when the reasons lead to external origins, crisis can be affected by natural disasters, political instabilities and terrorism, virus spreads, financial crises and etc. (Henderson, 2007). As a process, crisis management can be divided into three phases: precrisis, crisis response, and post-crisis (Faulkner, 2001). The tri-part view (Precrisis; Crisis response and Post-crisis) to crisis management theory is a basis for this part of chapter, where, based on chronological framework of crisis will be discussed best practices noticed by scholars. 
Nikadimovs \& Rodčenkova, 2021. Hospitality Industry During Covid-19 Crisis: Review of the Current Situation and Sustainable Post-Crisis Response

Pre-Crisis

Pre-Crisis or Prevention and Preparation stage involves reducing known internal and external risks that could lead to a crisis. Quick decision-making process is crucial point when dealing with the crisis, when the company decides how to manage situation, the main task is developing a flexible and fast internal organizational plan- evaluate and organize work within business structure, culture and society. Bundy et al. highlight the importance of identifying the first signs of the crisis to avoid a large impact and find important keep positive stakeholders' relationships towards company (Bundy et al., 2017). Coombs (2007) document that organizations are better able to handle crises when they have a Crisis Management Plan (CMP). The only disadvantage of CMP in the hospitality industry is informal and not-written strategy. Due to CMP is not documented in many hospitality industry' companies when the crisis appears- businesses suffer more (Henderson, 2007).

\section{Crisis Response}

According to Coombs (2007) crisis response strategy is divided into two parts according to field that should be repaired: initial crisis response and reputation repair. Initial crisis response stands for quick, accurate and consistent actions, when crisis occurs. Mainly all previously mentioned steps are handled by "crisis leaders", that take responsibility to lead organization during all stages. Powerful leaders make quicker decisions and reduce probability of organizations failure (James et al., 2011). The worst enemy for organization during crisis is time, in this case accuracy is important in terms of public relations. The time pressures and to not mislead society by making mistakes all information should be checked and be accurate (Faulkner, 2001). Crisis managers should express sympathy for victims of the crisis. Suffered might have lost their money, become ill or were injured by crisis in a different way. The studies have found that reputational experience of company is less damaged when company express concern about stakeholders and make public safety number one priority (Coombs \& Holladay, 1996).

\section{Post-crisis}

Post-crisis phase is a stage, when company returns to business as usual, and mainly focus operations on learning of new policies and changes. In this case, crisis should be taken into consideration as a challenge and opportunity, but not as a problem (Faulkner, 2001). Crisis management efforts should be evaluated and improved. As a part of CMP, that might be prepared before crisis hits, some practices should be discussed. Coombs (2007) recommends to deliver all information about company' future, that was promised, to stakeholders as soon as possible. According to the crisis management theories, post-crisis period is regarded as a time for learning (Coombs \& Laufer, 2018), a time for analysing the outcomes of the crisis situations and the effectiveness of the measures undertaken. 
Standard operating procedures and processes in the hotel industry are affected by the COVID-19 pandemic and the government restrictions, hospitality industry organizations should find new sustainable solutions to continue their operations under the present conditions.

\section{Discussion and Conclusions}

The papers included in this study reviewed different aspects of COVID-19 impact on tourism and hospitality industry, as well as possible sustainable crisis responses and solutions. The topics addressed in the papers were as follows: 1) revenue loss and market demands 2) health and safety issues 3 ) unemployment rates in the hospitality industry 4) job insecurity, hospitality workers' issues, loss of jobs 5) COVID-19 spreading patterns in the industry 6) sustainability in COVID-19 crisis 7) crisis and corporate sustainability 8) strategic management and crisis management plans.

The studies reviewed used predominantly secondary research data and can be qualified as reviews or exploratory studies, different aspects of COVID-19 were addressed, sustainability included. The studies that used primary data mostly utilized the survey and questionnaire research model and attempted to get an insightful perspective on the pandemic impact and negative effects on hospitality industry enterprises, by collecting the opinions of industry professionals and performing additional content analysis. Analysing questionnaire data and "conducting surveys" is the most popular primary data methods according to the studies reviewed. This approach also was used to measure social and behavioural aspects of the hospitality industry response to the COVID-19 pandemic.

While the majority of the papers has assessed pandemic's negative impact on tourism and hospitality industry, noting the rapid decrease in international arrival numbers, government limitations and catastrophic revenue losses, very few has addressed the sustainability issues and assessed the sustainable recovery strategic solutions and sustainable responses. The reviewed crisis management plans and mechanisms are mostly of theoretical background, however COVID-19 is a very real and ongoing pandemic (Iyer \& Jarvis, 2019). COVID-19 crisis can be used to develop a better crisis management strategy and to achieve a greater sustainability; this is the time to lean for this opportunity and redesign the tourism and hospitality industry landscape to make it more equitable and sustainable for the future (Benjamin et al., 2020). The World Travel and Tourism Council (2020) has stressed the economic importance of tourism and hospitality industries, emphasising the health and safety of all involved stakeholders, urging to develop efficiently sustainable crisis management solutions.

As it has been noted the aspect of COVID-19 spreading patterns in tourism and hospitality has been the most popular research topic, setting the tone for the 
whole research effort direction. Many studies concluded that finical surviving and resuming the operation are the main goals of many tourism and hospitality industry enterprises, while sustainability and especially social sustainability, should be addressed more carefully and extensively. The studies have shown that the new reality is expected to be permanent, as the travel behaviours, preferences of customers have been modified and social costs have been assessed and compared. More specifically, the hotels should develop new operating standards and protocols that would promote sustainable practices, both guests' and employees' health and safety, enhance travellers' confidence and minimise risks. The current ongoing pandemic should be used as the learning experience, to develop appropriate crisis management solutions.

In an overnight the pandemic of COVID-19 has confronted the hospitality industry. Travellers have changed their behaviour and have become very conscious about their travelling and hotel choices, and the time, when they will return back to previous habits, at the moment, is not predictable, if ever. Not only guests, but as well employees changed their mindsets, some of them are working at the moment, when some lost their jobs, and, as a result, it created distrustful relationship between the hospitality industry employers and employees. The previous successes of management in forging the relationship between management and employees is now erased or severely damaged due to massive job losses in the sector, and the confidence in the prosperous future of hospitality industry is lost. While the tourism and hospitality industry are no strangers to natural disasters or similar crises, the global COVID-19 pandemic has taken it to a new level, especially the sustainability issues. The companies do not have the opportunity to reallocate customers or guests, employees or any other stakeholders to alternative properties or locations, as it is a global pandemic and no such opportunities are present.

Finally, practical, operational and strategic implications in regards of developing a better crisis management framework are difficult to draw, given the fact that the pandemic is still ongoing and the tourism and hospitality industry is facing uncertain future. Pandemic is expected to be unpredictable; operations are no going to get back to normal as it was before $t$, industry needs to readjust itself to the new normal. Tourisms and hospitality industry organizations should pay additional attention to suitability issues and developing the proper solutions, guidelines and crisis management framework, thus multiplying the social capital, as it does have enormous potential not only to highlight the importance of sustainability factors, but also benefits cooperation and collective action. The lack or insufficient number of studies on suitability during the COVID-19 pandemic should be covered by the researchers, where they should focus on more timely and efficient solutions, rather than theorizing about possible benefits of certain 
strategic approaches, involving more sustainable approaches on all possible levels of involved stakeholders - individuals, businesses and authorities.

\section{Limitations and Future Research}

Several limitations can be outlined when conducting a literature review. The first limitation would be the time constraints and limited resources when searching and identifying relevant literature to review. Another limitation would be the number of available open-access resources and using a limited number of search databases for literature discovery. The lack of the empirical data and evidences can be mentioned as a limitation as well, thus the discussion in this study is based on other researches' opinions and findings, peered reviewed articles, commentaries and other literature. COVID-19 pandemic is an ongoing event and is very unpredictable, thus theoretical and practical implications of this study can be viewed as uncertain. Many studies are on the way and will definitely contribute to a broader scope and understanding of the problem, to designing better crisis responses and management strategies. With more evidence-based studies the researchers' community will provide better common ground for all hospitality industry stakeholders to find better solutions and pandemic coping mechanisms. This study cannot be viewed as exhaustive and comprehensive, as the nature of the review is interpretive and subjective, and can viewed in alternative ways by the other researchers. Altogether, the study provides a sufficient overview of the theoretical, strategic and research implications of the crisis management and sustainability issues in COVID-19 pandemic time in the hospitality industry. The future studies can utilise more evidence-based approach and conduct an empirical investigation on the impact of the pandemic, sustainability issues and possible technology integration as a post-crisis coping mechanism to enhance customers' experience, engagement, exceed satisfaction and improve loyalty, as well as to ensure full health and safety and 'new reality" standard operating procedures and protocols. Addressing the mentioned limitations and conducting empirical investigation will improve understanding of ongoing global pandemic and will improve the possible scenarios and outcomes.

\section{References}

Al Eid, N., \& Arnout, B. (2020). Crisis and disaster management in the light of the Islamic approach: COVID-19 pandemic crisis as a model (a qualitative study using the grounded theory). Journal of Public Affairs. DOI: https://doi.org/10.1002/pa.2217 Retrieved from: https://onlinelibrary.wiley.com/doi/full/10.1002/pa.2217

Armstrong, P., Armstrong, H., Choiniere, J., Lowndes, R., \& Struthers, J. (2020). Re-imagining long-term residential care in the COVID-19 crisis. Ottawa, ON: Canadian Centre for Policy Alternatives. 
Nikadimovs \& Rodčenkova, 2021. Hospitality Industry During Covid-19 Crisis: Review of the Current Situation and Sustainable Post-Crisis Response

Bakar, N. A., Rosbi, S. (2020). Effect of Coronavirus disease (COVID-19) to tourism industry. International Journal of Advanced Engineering Research and Science, 7, 189-193. DOI: 10.22161/ijaers.74.23.

Beirman, D. (2003). Marketing of tourism destinations during a prolonged crisis: Israel and the Middle East. Journal of Vocational Marketing, 8(2), 167-176. Retrieved from: https://www.researchgate.net/publication/240284977_Marketing_of_tourism_destinatio ns_during_a_prolonged_crisis_Israel_and_the_Middle_East

Bell, E., \& Bryman, A. (2018). Business Research Methods. Retrieved on 27.01.2021 from: https://www.uwcentre.ac.cn/haut/wp-

content/uploads/2018/11/Alan_Bryman_Emma_Bell_Business_Research_Methodsbok.cc.pdf

Benjamin, S., Dillette, A., \& Alderman, D. H. (2020). “We can’t return to normal”: committing to tourism equity in the post-pandemic age. Tourism Geographies, 22(3), 476-483. DOI: https://doi.org/10.1080/14616688.2020.1759130

Bundy, J., Pfarrer, M. D., Short, C. E., \& Coombs, W. T. (2017). Crises and Crisis Management: Integration, Interpretation, and Research Development. Retrieved from: https://journals.sagepub.com/doi/10.1177/0149206316680030

Cajner, T., Crane, L. D., Decker, R. A., Hamins-Puertolas, A., \& Kurz, C. (2020). Tracking Labor Market evelopments during the COVID-19 Pandemic: A Preliminary Assessment. Federal Reserve Board. Retrieved from: https://www.federalreserve.gov/ econres/feds/files/2020030pap.pdf

Caradonna J. L. (2014). Sustainability: A History. Retrieved from: https://books.google.lv/ books?id=GGrrAwAAQBAJ\&printsec=frontcover\#v=onepage \&q\&f=false

Central Statistical Bureau of Latvia. (2020). In October, the number of guests in tourist accommodation establishments continued to decrease. Retrieved from: https://www.csb.gov.lv/en/statistics/statistics-by-theme/transporttourism/tourism/search-in-theme/2890-latvian-hotels-and-other-accommodation

Choy, V., Chong, H., \& Verma, R. (2015). Cornell Hospitality Report. Environmental Sustainability in the Hospitality Industry: Best Practices, Guest Participation, and Customer Satisfaction. Retrieved from: https://ecommons.cornell.edu/bitstream/ handle/1813/71174/BrunsSmith_2015_Enviro_Sustain.pdf?sequence=1\&isAllowed=y

Coombs, W. T., Holladay, S. J. (1996). Communication and Attributions in a Crisis: An Experimental Study in Crisis Communication. Retrieved from: https://www.researchgate.net/publication/232958752_Communication_and_Attribution s_in_a_Crisis_An_Experimental_Study_in_Crisis_Communication

Coombs, W. T. (2007). Protecting organization reputations during a crisis: The development and application of situational crisis communication theory. Corporate Reputation Review, 10(3), 163-177.

Coombs, W. T., \& Laufer, D. (2018). Global Crisis Management - Current Research and Future Directions. Journal of International Management. DOI: https://doi.org/10.1016/ j.intman.2017.12.003

Crouch, E., Fitzgerald, M., Goad, N., Goldberg, A., Gordon, A., \& McCaleb, T. (2020). Breaking Ground on a New Era in Lodging. BCG. Retrieved from: https://www.bcg.com/en-au/publications/2020/understanding-consumerbehavior- inhotel-industry-post-covid-19

Dehler, N. (2020). COVID- 19 and Hospitality: Re-evaluating Your Hotel Technology Strategy to Prepare for a New Normal Post-Recovery. Retrieved from: 
https://www.stayntouch.com/resources/articles/covid-19-and-hospitality-re-evaluatingyour-hotel-technology-strategy-to-prepare-for-a-new-normal-post-recovery/

Duarte Alonso, A., Kok, S. K., Bressan, A., O'Shea, M., Sakellarios, N., Koresis, A., Buitrago Solis, M. A., \& Santoni, L. J. (2020). COVID-19, aftermath, impacts, and hospitality firms: An international perspective. International journal of hospitality management, 91, 102654. https://doi.org/10.1016/j.ijhm.2020.102654

Dung, L., \& Giang, P. (2020). Strategic responses of the hotel sector to COVID-19: Toward a refined pandemic crisis management framework. International Journal of Hospitality Management, 102808. DOI: https://doi.org/10.1016/j.ijhm.2020.102808

Ertuna, B., Karatas-Ozkan, M. and Yamak, S. (2019). Diffusion of sustainability and CSR discourse in hospitality industry: Dynamics of local context. International Journal of Contemporary Hospitality Management, Vol. 31, No. 6, 2564-2581

Eurostat. (2020). Impact of Covid-19 crisis on services. Retrieved from https://ec.europa.eu/eurostat/statistics-explained/index.php?title=Impact_of_Covid19_crisis_on_services

Faulkner, B. (2001). Towards a framework for tourism disaster management. Tourism management, 135-147.

Flick, U. (2014). An Introduction to Qualitative Research. Sage Publications, London. Retrieved from: https://books.google.lv/books/about/An_Introduction_to_Qualitative_Research.html?id =HB-VAgAAQBAJ\&redir_esc=y

Global Reporting Initiatives (GRI). (2006). Sustainability Reporting Guidelines for Public and Third Sector Organizations. Retrieved from: https://www.globalreporting.org/

Gössling, S., Scott, D., \& Hall, C.M. (2020). Pandemics, tourism and global change: a rapid assessment of COVID-19. Journal of Sustainable Tourism, 29:1, 1-20, DOI: 10.1080/09669582.2020.1758708

Hall, M. (2010). Crisis events in tourism: subjects of crisis in tourism. Current Issues in Tourism, 13(5), 401-417. DOI: 10.1080/13683500.2010.491900

Hao, F., Xiao, Q., \& Chon, K. (2020). COVID-19 and China's Hotel Industry: Impacts, a Disaster Management Framework, and Post-Pandemic Agenda. International Journal of Hospitality Management, 90, 102636. DOI: 10.1016/j.ijhm.2020.102636.

Henkel, A., Caic, M., Blaurock, M., \& Okan, M. (2020). Robotic transformative service research: deploying social robots for consumer well-being during COVID-19 and beyond. Journal of Service Management, 31, 1131-1148. DOI: 10.1108/JOSM-05-2020-0145.

Henderson, J. (2006). International tourism and infectious disease: Managing the SARS crisis in Singapore. Crisis Management in Tourism. 186-199.

Iyer, G. R., \& Jarvis, L. (2019). CSR adoption in the multinational hospitality context: A review of representative research and avenues for future research. International Journal of Contemporary Hospitality Management, Vol. 31, No. 6, 2376-2393.

James, P., Magee, L., Scerri, A., \& Steger, M. B. (2015). Urban Sustainability in Theory and Practice: Circles of Sustainability. U.K.: Routledge.

Jones, P., Hillier, D., \& Comfort, D. (2014). Sustainability in the global hotel industry. International Journal of Contemporary Hospitality Management, 26. 10.1108/IJCHM10-2012-0180.

Jones, P., Comfort, D. (2020). The COVID-19 Crisis and Sustainability in the Hospitality Industry. International Journal of Contemporary Hospitality Management. Retrieved from: http://eprints.glos.ac.uk/8539/1/8539-Jones-\%282020\%29-The-COVID-19Crisis-and-Sustainability.pdf 
Nikadimovs \& Rodčenkova, 2021. Hospitality Industry During Covid-19 Crisis: Review of the Current Situation and Sustainable Post-Crisis Response

Karatepe, O. M., Rezapouraghdam, H., \& Hassannia, R. (2020). Job insecurity, work engagement and their effects on hotel employees' non-green and nonattendance behaviors. Int. J. Hosp. Manage. 87(May), 1-12.

Kastsadze, B., \& Milojevic, D. (2020). Social Sustainability in COVID-19 Crisis: The Case of the Hotel Industry. Retrieved from: http://www.diva-portal.org/smash/ get/diva2:1441677/FULLTEXT01.pdf

Kramer, M. R. \& Porter, M. (2011). Creating shared value. FSG. Retrieved from: https://hbr.org/2016/10/the-ecosystem-of-shared-value

Maaty, D. (2020). Evolving guest behaviour due to COVID-19 will trigger technology shift. Hotel News me. Retrieved from: https://www.hotelnewsme.com/news/evolving-guestbehaviour-due-to-covid-19-will-trigger-technology-shift-four-seasons-it-director-says/

Min, J. C., Lim, C., \& Kung, H.H. (2011). Intervention analysis of SARS on Japanese tourism demand for Taiwan. Qual. Quant, 45 (1), 91-102. DOI: https://doi.org/10.1007/s11135010-9338-4.

Nazneen, S., Hong, X., \& Ud Din, N. (2020). COVID-19 Crises and Tourist Travel Risk Perceptions. SSRN, 3592321. Retrieved from: https://papers.ssrn.com/sol3/ papers.cfm?abstract_id=3592321

Nkengasong, J. (2020). China's response to a novel coronavirus stands in stark contrast tonthe 2002 SARS outbreak response. Nat. Med. 26, 310-311. DOI: https://doi.org/10.1038/

Qiu, R. T., Park, J., Li, S., \& Song, H. (2020). Social costs of tourism during the COVID-19 pandemic. Ann. Tour. Res. 84, 102994.

Radhakrishna, S. A. (2020). COVID-19 | Post-pandemic, India's Tourism Sector Stares at 70\% Job Loss. Retrieved from: https://www.thehindu.com/news/nationa

Ritchie, B. W., \& Jiang, Y. (2019). A review of research on tourism risk, crisis and disaster management: Launching the annals of tourism research curated collection on tourism risk, crisis and disaster management, Annals of Tourism Research, Volume 79,102812, DOI: https://doi.org/10.1016/j.annals.2019.102812.

Rivera, M. (2020). Hitting the reset button for hospitality research in times of crisis: COVID19 and beyond. International Journal of Hospitality Management. DOI: 10.1016/j.ijhm.2020.102528

Ryan, G. (2018). Postpositivist critical realism: philosophy, methodology and method for nursing research. Nurse Researcher, 27. DOI: 10.7748/nr.2019.e1598.

Schutz, A. (1962). The Phenomenology of the Social World. Retrieved from: https://plato.stanford.edu/entries/schutz/\#PheSocWor

Seeger, M., Ulmer, R. R., \& Sellnow, T. L. (2005). Post-Crisis Discourse and Organizational Change, Failure and Renewal. Journal of Organizational Change Management, 18, 7895. DOI: $10.1108 / 09534810510579869$.

Sigala, M. (2020). Tourism and COVID-19: Impacts and implications for advancing and resetting industry and research. Journal of Business Research, 117, DOI: 10.1016/j.jbusres.2020.06.015.

State Employment Agency Republic of Latvia. (2020). Retrieved from: https://www.nva.gov.lv/en/unemployment-statistics-2

Stake, R. E. (1995). The Art of Case Study Research. Retrieved from: https://books.google.lv/books?id=ApGdBx76b9kC\&printsec $=$ frontcover\#v=onepage $\& q$ \&f=false

Stake, R. E. (2005). Qualitative Case Studies. In: N. K. Denzin \& Y. S. Lincoln (Eds.), The Sage handbook of qualitative research, Sage Publications Ltd, 443-466. 
Statista. (2020). Number of jobs at risk in the tourism sector in European countries due to the coronavirus (COVID-19) pandemic in 2020. Retrieved from: https://www.statista.com/ statistics/1107432/travel-and-tourism-jobs-at-risk-europe-coronavirus/

United Nations. (2020). COVID-19 likely to shrink global GDP by almost one per cent in 2020. Retrieved from: https:/www.un.org/sustainabledevelopment/blog/2020/04/covid-19likely-to-shrink-global-gdp-by-almost-one-per-cent-in-2020

University of Michigan. (2002). Sustainability Assessment and Reporting for the University of Michigan's Ann Arbor Campus, p.8. Retrieved from http://css.umich.edu/ sites/default/files/css_doc/CSS02-04.pdf

Weber, M. (1947). The theory of social and economic organization (1st Amer. ed.). Oxford University Press.

Wen, J., Kozak, M., Yang, S., \& Liu, F. (2020). COVID-19: potential effects on Chinese citizens' lifestyle and travel. Tourism Review. DOI: https://doi.org/10.1108/TR-03-20200110

Western Australian Council of Social Service (WACOSS). (2003). WACOSS Housing and Sustainable Communities Indicators Project. Retrieved from: http://www.regional.org.au/au/soc/2002/4/barron_gauntlett.htm

WEF (WEF). (2020). Global Competitiveness Report Special Edition 2020: How Countries are Performing on the Road to Recovery. Retrieved from: https://www.weforum.org/ reports/the-global-competitiveness-report-2020

World Health Organization, (WHO). (2020). Pneumonia of unknown cause - China. Retrieved on 11.01.2021 from: https://www.who.int/csr/don/05-january-2020-pneumonia-ofunkown-cause-china/en/

World Travel \& Tourism Council (WTTC). (2020). COVID-19 Hub. Retrieved from: https://wttc.org/COVID-19

World Travel \& Tourism Council (WTTC). (2020). "Leading Global Protocols for the New Normal”. Retrieved on 15.01.2021 http://aifec.org/web/wp-content/uploads/2020/05/ Global_Protocols_for_the_New_Normal__Convention_Centres.pdf 